\title{
Pengaruh Penambahan Natrium Benzoat dan Suhu Penyimpanan terhadap Mutu Minuman Herbal Cabe Jamu Cair
}

Millatul Ulya, Nadiyah Ferah Aronika, Khoirul Hidayat

Teknologi Industri Pertanian, Universitas Trunojoyo Madura

irul_ie@yahoo.co.id

DOI: https://doi.org/10.21107/rekayasa.v13i1.5385

\begin{abstract}
ABSTRAK
Minuman herbal cabe jamu cair merupakan inovasi produk baru yang masih perlu dikaji tentang metode pengawetannya. Penelitian ini bertujuan untuk mengetahui pengaruh penambahan konsentrasi natrium benzoat dan suhu penyimpanan terhadap mutu minuman herbal cabe jamu cair. Rancangan yang digunakan dalam penelitian ini adalah Rancangan Acak Lengkap (RAL) dengan 2 faktor yaitu pengaruh konsentrasi natrium benzoat (0 ppm, 200 ppm, 300 ppm) dan suhu penyimpanan $\left(35\right.$ dan $\left.45^{\circ} \mathrm{C}\right)$. Hasil analysis of variance menunjukkan konsentrasi natrium benzoat berpengaruh nyata (P kurang dari 0,05 ) terhadap total padatan terlarut (TPT), warna dan total mikroba. Suhu penyimpanan berpengaruh nyata (P kurang dari 0,05$)$ terhadap total padatan terlarut (TPT), warna, dan total mikroba. Interaksi antara konsentrasi natrium benzoat dan suhu penyimpanan berpengaruh nyata (P kurang dari 0,05 ) terhadap total padatan terlarut (TPT).
\end{abstract}

Kata Kunci: Cabe jamu, natrium benzoat, suhu penyimpanan, mutu

\section{Effect of Sodium Benzoate Addition And Storage Temperature on Quality of Piper Retrofractum Vahl Liquid Herbal Drink}

\section{ABSTRACT}

Piper retrofractum vahl liquid herbal drink is an innovation of new products need to research about method. This research aims to determine the effect of sodium benzoate addition and storage temperature on quality of piper retrofractum vahl liquid herbal drink. The design used in this study was a completely randomized design (CRD) with 2 factors, namely the effect of sodium benzoate concentration $(0 \mathrm{ppm}, 200 \mathrm{ppm}, 300 \mathrm{ppm})$ and storage temperature $\left(35^{\circ} \mathrm{C}\right.$ and $45^{\circ} \mathrm{C}$ ). The results analysis of variance show that the concentration of sodium benzoate has a significant effect (P less than 0.05 ) on total dissolved solids (TDS), color and total microbes. Storage temperature has a significant effect (P less than 0.05 ) on total dissolved solids (TDS), color and total microbes. The interaction between sodium benzoate concentration and storage temperature was significant effect (P less than 0.05) to total dissolved solids (TDS).

Keywords: piper retrofractum vahl, sodium benzoate, storage temperature, quality .

\section{PENDAHULUAN}

Tanaman Cabe jamu atau cabe jawa (Piper retrofractum Vahl) merupakan tanaman rempah dan fitofarmaka asal Indonesia yang banyak tersebar di Jawa Timur dan Lampung yang digunakan sebagai obat tradisional bagi masyarakat atau bagi industri makanan, minuman, jamu dan obat (Evizal, 2013). Tanaman cabe jamu memiliki kandungan alkaloid, saponin, tanin, flavonoid, steroid, triferpenoid, glikosida, piperin (sekitar 4-6\%), piperlonguminine, slvatine, tiltilime, sitosterol, sitrat dan linalool yang tersebar diseluruh organ daun, batang, buah dan akar tanaman cabe jamu. Dari kandungan tersebut maka cabe jamu memiliki banyak manfaat bagi kesehatan diantaranya asma, sakit kepala, kejang perut, infeksi bakteri dan masuk angin (Zuchri, 2008). Banyaknya kandungan dan manfaat tanaman tersebut membuat tanaman cabe jamu banyak dimanfaatkan sebagai tanaman obat herbal atau

\section{Article History:}

Received: June 12th 2019: Accepted: January, 12th 2020

ISSN: 2502-5325 (Online) Terakreditasi Peringkat 3 oleh Kementerian Riset, Teknologi dan Pendidikan Tinggi (ARJUNA) berdasarkan Keputusan Direktur Jenderal Penguatan Riset dan Pengembangan No: 23/E/KPT/2019 tanggal 8 Agustus 2019 jamu tradisional khususnya di daerah Madura. Dengan perkembangan teknologi maka beberapa produsen mulai mengembangkan produk cabe jamu menjadi minuman herbal cabe jamu cair (Mu'tamar et al. 2019).

Pembuatan minuman cabe jamu cair masih perlu dikaji tentang metode pengawetannya untuk memperpanjang daya simpannya. Karena bentuknya yang cair, umur simpannya relatif rendah. Salah satu alternatif untuk memperpanjang daya simpannya adalah dengan menambahkan bahan pengawet, seperti natrium benzoat.

Natrium benzoat bersifat aktif untuk menghambat pertumbuhan bakteri dan khamir, tetapi kurang efektif terhadap kapang. Benzoat pada khamir memiliki kemampuan pertumbuhan yang berbeda-beda. Penggunaan natrium benzoat biasa-

\section{Cite this as:}

Ulya, M. Aronika, N.F. \& Hidayat, K. (2020). Pengaruh Penambahan Natrium Benzoat dan Suhu Penyimpanan terhadap Mutu Minuman Herbal Cabe Jamu Cair. Rekayasa, 13(1), 77-81. doi: https://doi.org/10.21107/rekayasa.v13i1.5385

(c) 2020 Author(s) 
78 | Ulya, M. dkk. Pengaruh Penambahan Natrium Benzoat dan Suhu Penyimpanan...

nya berbentuk garam seperti garam natrium atau ammonium. Penggunaan dalam bentuk garam lebih efektif dari pada berbentuk asam karenanya lebih muda larut. Kelarutan asam benzoat dalam air 0,35\% sedangkan dalam bentuk garam natrium memiliki kelarutan 50\% (Estiasih, 2015). Batas maksimum penggunaan natrium benzoat pada minuman ringan yakni 600 mg/kg (BSN, 1995).

Penelitian ini bertujuan untuk mengetahui pengaruh penambahan konsentrasi natrium benzoat dan suhu penyimpanan terhadap mutu minuman herbal cabe jamu cair.

\section{METODE PENELITIAN}

Metode yang digunakan dalam penelitian ini eksperimental, yang dilakukan menggunakan percobaan dengan rancangan acak lengkap (RAL).

\section{Bahan dan Alat}

Bahan yang digunakan dalam pembuatan cabe jamu cair antara lain, cabe jamu kering, natrium benzoat, gula, air, dan alumunium foil. Sedangkan bahan untuk uji produk akhir adalah aquadest, PCA (Plate Count Agar), tissue, kapas, dan $\mathrm{Na}_{2} \mathrm{CO}_{3}$.

Alat yang digunakan untuk membuat cabe jamu cair adalah timbangan digital, panci bertekanan (presto) dan kompor. Sedangkan alat untuk uji produk akhir adalah gelas ukur, beaker glass, bunsen, pHmeter, refraktometer, autoclave, mikropipet, color reader, dan colony counter.

\section{Rancangan penelitian}

Penelitian ini menggunakan Rancangan Acak Lengkap Faktorial (RALF) dengan 2 faktor yang diteliti yaitu konsentrasi natrium benzoat $(0,200$, dan 400 ppm) dan suhu penyimpanan dengan (35 dan $45^{\circ} \mathrm{C}$ ) dengan 3 kali ulangan. Rancangan penelitian seperti terlihat pada Tabel 1 .

\section{Proses Produksi minuman herbal cabe jamu cair}

Minuman herbal cabe jamu cair merupakan ekstrak dari tanaman cabe jamu yang sudah dikeringkan. Pencampuran cabe jamu dan air dengan perbandingan (100 gram : 1 Liter). Pemanasan menggunakan panci bertekanan (presto) dengan menunggu sampai mencapai tekanan 15 lbs dengan suhu $121^{\circ} \mathrm{C}$, setelah suhu dan tekanan sudah mencapai standar maka produk dipanaskan selama 30 menit, selanjutkan api dimatikan, didinginkan dan ditambahkan gula dengan konsentrasi 100 g/L. Kemu-

Tabel 1. Rancangan penelitian

\begin{tabular}{lll}
\hline Konsentrasi Natrium Benzoat & $\begin{array}{c}\text { Suhu } 35^{\circ} \mathrm{C} \\
(\mathrm{T} 1)\end{array}$ & $\begin{array}{c}\text { Suhu } 45^{\circ} \mathrm{C} \\
(\mathrm{T} 2)\end{array}$ \\
\hline Tanpa Natrium Benzoat 0 ppm (A1) & A1T1 & A1T2 \\
Natrium Benzoat 200 ppm (A2) & A2T1 & A2T2 \\
Natrium Benzoat 400 ppm (A3) & A3T1 & A2T3 \\
\hline
\end{tabular}

dian dipanaskan kembali yang bertujuan untuk mencampurkan gula dan cabe jamu cair. Setelah itu penambahan konsentrasi natrium benzoat sebanyak 0 ppm, 200 ppm dan 400 ppm. Terakhir yaitu proses pengemasan sebanyak $20 \mathrm{~mL}$ dalam kemasan alumunium foil.

Semua unit percobaan selanjutnya disimpan pada suhu $\left(35^{\circ} \mathrm{C}\right.$ dan $45^{\circ} \mathrm{C}$ ) selama 28 hari (4 minggu) dan selanjutnya diuji mutu produknya menggunakan beberapa parameter uji.

\section{Parameter penelitian}

Produk cabe jamu cair yang telah diproduksi akan diuji $\mathrm{pH}$, total padatan terlarut, warna dan total mikroba yang dihasilkan dengan prosedur sebagai berikut.

\section{Uji pH (AOAC, 1995)}

Pengujian mengukur nilai $\mathrm{pH}$ dilakukan dengan menggunakan alat pHmeter pada minuman herbal cabe jamu cair. Sebelum digunakan, pHmeter terlebih dahulu dikalibrasi dengan larutan buffer.

\section{Uji Total Padatan Terlarut (TPT) (AOAC, 1995)}

Pengujian TPT menggunakan alat refraktometer dibersikan bagian kacanya dengan cara meneteskan aquades hingga merata dan bersihkan dengan tissue hingga permukaan kaca refraktometer kering. Meneteskan sampel sebanyak 2-3 tetes pada bagian kaca depan refraktometer dan dilakukan pembacaan skala.

\section{Uji Warna (Hutching, 1999)}

Analisis warna menggunakan color reader. Sebelum dilakukan pengukuran alat terlebih dahulu dikalibrasi dengan menggunakan plat yang sesuai dengan warna sampel. Pengukuran dilakukan dengan meletakkan alat diatas sampel.

\section{Uji Total mikroba (BAM 2001 dalam Wulandari 2014)}

Analisi total mikroba dilakukan dengan mengencerkan $1 \mathrm{~mL}$ sampel kedalam $9 \mathrm{~mL}$ aquadest, pada tingkat pengenceran $10^{1}, 10^{2}, 10^{3}, 10^{4}$, dan $10^{5}$ pada tabung reaksi. Menuangkan 12-15 mL PCA (Plate Count Agar) ke dalam cawan petri dan menunggu sampai agar mengeras, kemudian menanam $1 \mathrm{~mL} 3$ pengeceran terakhir dan cawan kemudian menggunakan triangel untuk menyebarkan sel-sel mikroba secara merata, setelah itu membungkus dengan kertas dan disimpan pada suhu $35^{\circ} \mathrm{C}$ selama $2 \times 24$ jam (48 jam). Setelah inkubasi, jumlah koloni yang tumbuh dihitung.

\section{HASIL DAN PEMBAHASAN Power of Hidrogen $(\mathrm{pH})$}

Analisis nilai pH dilakukan untuk mengetahui perubahan karakteristik tingkat keasaman minuman herbal cabe jamu cair selama penyimpanan dengan penambahan natrium benzoat. 
Tabel 2. Analisis pengaruh konsentrasi natrium benzoat dan suhu penyimpanan terhadap nilai $\mathrm{pH}$ cabe jamu cair

\begin{tabular}{|c|c|c|c|c|c|}
\hline $\begin{array}{l}\text { Sumber } \\
\text { Variansi }\end{array}$ & Db & JK & RJK & $\mathbf{F}$ & Sig. \\
\hline $\begin{array}{c}\text { Konsentrasi } \\
\text { Natrium } \\
\text { Benzoat }\end{array}$ & 2 & 0,601 & 0,301 & 1,537 & 0,289 \\
\hline $\begin{array}{l}\text { Suhu Penyim- } \\
\text { panan }\end{array}$ & 1 & 0,025 & 0,025 & 0,129 & 0,732 \\
\hline $\begin{array}{l}\text { Konsentrasi } \\
\text { Natrium ben- } \\
\text { zoat*Suhu } \\
\text { Penyimpanan }\end{array}$ & 2 & 0,020 & 0,010 & 0,052 & 0,950 \\
\hline Eror & 6 & 1,174 & 0,196 & & \\
\hline Total & 12 & 62,688 & & & \\
\hline
\end{tabular}

Keterangan : db: derajat bebas; JK: Jumlah Kuadran; RJK: Rerata Jumlah Kuadran; F: nilai $F_{\text {hitung }}$; Signifikansi: 0,05

Tabel 2. Menunjukkan bahwa penambahan konsentrasi natrium benzoat, suhu penyimpanan, dan interaksi konsentrasi natrium benzoat terhadap suhu penyimpanan tidak memberikan pengaruh nyata terhadap nilai $\mathrm{pH}$ pada penyimpanan 28 hari. Konsentrasi penambahan natrium benzoat dapat menghambat penurunan nilai $\mathrm{pH}$, dikarenakan fungsi natrium benzoat merupakan sebagai bahan pengawet pangan yang dapat mencegah pertumbuhan mikro-organisme. Hal itu dibuktikan dengan semakin banyak penambahan natrium benzoat pada cabe jamu cair maka penurunan nilai $\mathrm{pH}$ semakin rendah. Semakin banyak penambahan natrium benzoat, maka semakin efektif proses penghambatan mikroorganisme (Fardiaz, 1989).

Semakin tinggi nilai $\mathrm{pH}$ maka tingkat keasaman produk semakin rendah sedangkan semakin rendah nilai $\mathrm{pH}$ maka keasaman produk semakin tinggi. Nilai $\mathrm{pH}$ pada bahan pangan umumnya 3-8 maka dari itu pH menjadi salah satu faktor pengendalian utama pertumbuhan mikroba pada bahan pangan (Pujihastuti, 2007).

\section{Total Padatan Terlarut (TPT)}

Analisis Total Padatan Terlarut (TPT) dilakukan untuk mengetahui berapa padatan yang terlarut pada masing-masing perlakuan. Hasil analisis variansi pada parameter TPT dapat dilihat pada Tabel 3. Tabel 3. Menunjukkan bahwa penambahan konsentrasi natrium benzoat, suhu penyimpanan, dan interaksi konsentrasi natrium benzoat terhadap suhu penyimpanan pada nilai TPT penyimpanan 28 hari. Penambahan natrium benzoat, suhu penyimpanan dan interaksi antara konsentrasi natrium benzoat terhadap suhu penyimpanan memberikan pengaruh nyata terhadap nilai TPT pada penyimpanan 28 hari dengan nilai signifikansi 0,$011 ; 0,001$ dan $0,021(P<0,05)$.

Penambahan konsentrasi natrium benzoat dapat menghambat penurunan nilai total padatan ter-
Tabel 3. Pengaruh konsentrasi natrium benzoat dan suhu penyimpanan terhadap nilai TPT cabe jamu cair

\begin{tabular}{cccccc}
\hline $\begin{array}{c}\text { Sumber } \\
\text { Variansi }\end{array}$ & db & JK & RJK & F & Sig. \\
\hline $\begin{array}{c}\text { Konsentrasi Natri- } \\
\text { um Benzoat }\end{array}$ & 2 & 0,451 & 0,226 & 10,314 & 0,011 \\
$\begin{array}{c}\text { Suhu Penyimpanan } \\
\text { Konsentrasi Natri- } \\
\text { um benzoat*Suhu } \\
\text { Penyimpanan }\end{array}$ & 1 & 0,992 & 0,992 & 45,343 & 0,001 \\
$\quad$ Eror & 6 & 0,341 & 0,171 & 7,800 & 0,021 \\
Total & 12 & 1353,418 & 0,022 & & \\
& & & & \\
\hline
\end{tabular}

Keterangan : db: derajat bebas; JK: Jumlah Kuadran; RJK: Rerata Jumlah Kuadran; F: nilai $\mathrm{F}_{\text {hitung }}$; Signifikansi: 0,05

larut, dikarenakan natrium benzoat merupakan zat pengawet yang efektif terhadap menghambat pertumbuhan mikrobia. Penambahan natrium benzoat yang dapat berikatan dengan membran sel mikrobia akan menurunkan kemampuan mikroorganisme untuk mentransporkan bahan-bahan penting bagi sel sehingga akan mengganggu proses metabolisme sel mikrobia (Estiasih et al. 2015). Semakin terhambatnya pertumbuhan mikroorganisme maka jumlah mikroorganisme yang dapat memfermentasi sukrosa akan semakin rendah hal ini dapat menurunkan nilai padatan terlarut pada cabe jamu cair.

Menurunnya nilai TPT pada minuman menunjukkan terjadinya penurunan kadar sukrosa dalam minuman. Menurut Farikha et al. (2013), nilai TPT yang semakin menurun diduga disebabkan karena adanya aktivitas fermentasi oleh mikroorganisme yang mengubah karbohidrat (sukrosa) menjadi substrat utama yang dipecah oleh mikroba dalam proses fermentasi menjadi gula yang lebih sederhana. Karbohidrat (dalam hal ini sukrosa) menjadi substrat utama yang dipecah oleh mikroba dalam proses fermentasi menjadi unit-unit gula lebih sederhana.

\section{Warna}

Hasil analisis variansi pada parameter warna dapat dilihat pada Tabel 4.

Tabel 4. Menunjukkan bahwa penambahan natrium benzoat dan suhu penyimpanan memberikan pengaruh nyata terhadap nilai warna pada penyimpanan 28 hari dengan nilai signifikansi 0,002 dan $0,002 \quad(P<0,05)$ sedangkan interaksi antara konsentrasi natrium benzoat terhadap suhu penyimpanan tidak memberikan pengaruh nyata dengan nilai signifikansi $0,816(P>0,05)$ terhadap nilai warna pada penyimpanan 28 hari.

Semakin banyak penambahan natrium benzoat akan membuat penurunan warna semakin rendah. Pada cabe jamu cair parameter warna dengan nilai terendah adalah pada cabe jamu cair tanpa penambahan natrium benzoat dan yang memiliki nilai parameter warna tertinggi yakni pada penam- 
80 | Ulya, M. dkk. Pengaruh Penambahan Natrium Benzoat dan Suhu Penyimpanan...

Tabel 4. Analisis pengaruh konsentrasi natrium benzoat dan suhu penyimpanan terhadap nilai warna pada cabe jamu cair

\begin{tabular}{|c|c|c|c|c|c|}
\hline $\begin{array}{l}\text { Sumber } \\
\text { Variansi }\end{array}$ & $\mathbf{d b}$ & JK & RJK & $\mathbf{F}$ & Sig. \\
\hline $\begin{array}{l}\text { Konsentra- } \\
\text { si Natrium } \\
\text { Benzoat }\end{array}$ & 2 & 3,372 & 1,686 & 20,230 & 0,002 \\
\hline $\begin{array}{l}\text { Suhu Penyim- } \\
\text { panan }\end{array}$ & 1 & 2,430 & 2,430 & 29,160 & 0,002 \\
\hline $\begin{array}{l}\text { Konsentra- } \\
\text { si Natrium } \\
\text { benzoat*Suhu } \\
\text { Penyimpanan }\end{array}$ & 2 & 0,035 & 0,18 & 0,210 & 0,816 \\
\hline Eror & 6 & 0,500 & 0,083 & & \\
\hline Total & 12 & 2297,140 & & & \\
\hline
\end{tabular}

bahan natrium benzoat $400 \mathrm{ppm}$. menurut Mailoa (2012), perubahan warna pada bahan pangan dapat disebabkan oleh tumbuhnya mikroorganisme yang dapat mempengaruhi perubahan warna, tekstur dan aroma pangan, membuat pangan tidak layak dikonsumsi.

Selain itu, suhu penyimpanan juga mempengaruhi tingkat kecerahan warna cabe jamu cair dimana, nilai paling gelap pada cabe jamu cair tanpa natrium benzoat pada penyimpanan suhu $45^{\circ} \mathrm{C}$ dan nilai kecerahan paling tinggi pada cabe jamu cair dengan penambahan natrium benzoat $400 \mathrm{ppm}$ pada suhu penyimpanan $35^{\circ} \mathrm{C}$. Perlakuan pemanasan dan penyimpanan jangka panjang juga dapat mengubah warna menjadi gelap, perubahan warna dari reaksi kompleks yang akan menghasilkan pigmen coklat melanoidin pada akhir reaksi atau sering disebut reaksi Maillard (Rahasti, 2008).

\section{Total Mikroba}

Total mikroba merupakan salah satu parameter pengujian untuk mengetahui mutu pada produk cabe jamu cair selama penyimpanan. Hasil analisis variansi parameter warna pada cabe jamu cair dapat dilihat pada Tabel 5.

Tabel 5. Menunjukkan bahwa penambahan konsentrasi natrium benzoat memberikan pengaruh nyata dengan nilai signifikansi $0,011(P<0,039)$ sedangkan suhu penyimpanan dan interaksi konsentrasi natrium benzoat terhadap suhu penyimpanan tidak memberikan pengaruh nyata terhadap nilai total mikroba pada penyimpanan 28 hari.

Menurut Winarno (1982), benzoat merupakan bahan pengawet yang digunakan untuk mencega pertumbuhan bakteri dan khamir pada bahan makanan. Mekanisme cara kerja natrium benzoat sebagai pengawet adalah mengganggu sel mikroba, karena isi sel mikroba mempunyai pH yang selalu netral jika sel mikroba menjadi asam atau basa akan terjadi gangguan pada organ-organ sel sehingga metabolisme akan terhambat dan akhirnya sebagian sel akan mati (Khurniyati dan Teti, 2015).
Tabel 5. Analisis pengaruh konsentrasi natrium benzoat dan suhu penyimpanan terhadap nilai total mikroba pada cabe jamu cair

\begin{tabular}{lccccc}
\hline $\begin{array}{c}\text { Sumber } \\
\text { Variansi }\end{array}$ & db & JK & RJK & F & Sig. \\
\hline $\begin{array}{c}\text { Konsentrasi } \\
\text { Natrium } \\
\text { Benzoat }\end{array}$ & 2 & 242,000 & 121,000 & 10,446 & 0,011 \\
$\begin{array}{c}\text { Suhu Penyim- } \\
\text { panan } \\
\text { Konsentrasi }\end{array}$ & 1 & 60,750 & 60,750 & 5,245 & 0,062 \\
$\begin{array}{c}\text { Natrium ben- } \\
\text { zoat*Suhu } \\
\text { Penyimpanan }\end{array}$ & 2 & 2,000 & 1,000 & 0,086 & 0,918 \\
$\quad$ Eror & 6 & 69,500 & 11,583 & & \\
\hline Total & 12 & 9615,000 & & & \\
\hline
\end{tabular}

Keterangan : db: derajat bebas; JK: Jumlah Kuadran; RJK: Rerata Jumlah Kuadran; F: nilai $\mathrm{F}_{\text {hitung; }}$ Signifikansi: 0,05

\section{SIMPULAN DAN REKOMENDASI}

Kesimpulan penelitian ini adalah konsentrasi natrium benzoat berpengaruh nyata $(P<0,05)$ terhadap total padatan terlarut (TPT) dan warna. Suhu penyimpanan berpengaruh nyata $(P<0,05)$ terhadap total padatan terlarut (TPT), warna, dan total mikroba. Interaksi antara konsentrasi natrium benzoat dan suhu penyimpanan berpengaruh nyata $(P<0,05)$ terhadap total padatan terlarut (TPT).

\section{DAFTAR PUSTAKA}

[AOAC] Association of Official Analytical Chemistry. 1995. Official Methods of Analysis 932.12 Solids (Soluble) in Fruits and Fruit Products. Virginia.

[AOAC] Association of Official Analytical Chemistry. 1995. Official Methods of Analysis 981.12 $\mathrm{pH}$ of Acidified Foods. Virginia.

Badan Standardisasi Nasional Indonesia. 1995. Bahan Tambahan Pangan.

Estiasih, T., Putri, W dan Widyastuti, E. 2015. Komponen Minor dan Bahan Tambah Pangan. Jakarta: PT. Bumi Aksara.

Evizal, R. 2013. Status Fitofarmaka dan Perkembangan Agroteknologi Cabe Jawa (Piper Retrofractum Vahl.). Jurnal Agrotropika. 18(1):34-40.

Fardiaz, S. 1989. Mikrobiologi Pangan PUA Pangan dan Gizi. Bogor: IPB

Farikha, N.I., Amam, C dan Widowati, E. 2013. Pengaruh Jenis Dan Konsentrasi Bahan Penstabil Alami Terhadap Karakteristik Fisikokimia Sari Buah Naga Merah (Hylocereus Polyrhizus) Selama Penyimpanan. Jurnal Teknosains Pangan. 2(1):30-39.

Hutching, John B. 1999. Food Color and Appearance. 2nd ed. Maryland: Aspen Publisher, Inc. 
Khurniyati, M. dan Teti, E. 2015. Pengaruh Konsentrasi Natrium Benzoat dan Kondisi Pasteurisasi (Suhu dana Waktu) Terhadap Karakteristik Minuman Sari Apel Berbagai Varietas: Kajian Pustaka. Jurnal Pangan dan Agroindustri. 3(2):523-529.

Mailoa, M. 2012. Pengaruh Natrium Benzoat dan Lama Penyimpanan Terhadap Mutu Selai Gandaria. Jurnal EKOSAINS. 1(1):21-27.

Mu'tamar, M.F.F., Ulya, M., dan Hidayat, K., 2019. "Product development of black Piper retrofractum Vahl tea (black PrV tea)," in IOP Conf. Ser.: Earth Environ. Sci.
Pujihastuti, D. 2007. Pengaruh Konsentrasi Natrium Benzoat Terhadapp Umur Simpan Minuman Beraroma Apel. [Skripsi]. Fakultas Teknologi Pertanian. Institut Pertanian Bogor. Bogor.

Rahasti, H. 2008. Pengaruh Konsentrasi Natrium Benzoat Terhadap Perubahan Mutu Pikel Jahe (Zingiber Officinale) Selama Penyimpanan. [Skripsi]. Departemn Teknologi Industri Pertanian. Institut Pertanian Bogor. Bogor.

Zuchri, A. 2008. Habitus dan Pencirian Tanaman Cabe Jamu (Piper retrofractum Vahl.) Spesifik Madura. AGROVIGOR. 1(1):39-45. 